\title{
Evaluation of land farming and chemico-biological stabilization for treatment of heavily contaminated sediments in a tropical environment
}

\author{
*R. H. Adams; F. J. Guzmán-Osorio \\ Laboratorio de Biorremediación, División Académica de Ciencias Biológicas, Universidad Juárez Autónoma de \\ Tabasco. Carretera Villahermosa-Cárdenas Km 0.5, Villahermosa, Tabasco, México \\ Received 29 January 2008; revised 19 February 2008; accepted 28 February 2008; available online 10 March 2008
}

\begin{abstract}
Conventional and experimental methods were studied for the remediation of petroleum contaminated sediments from a dam previously used to collect acid run-off from a sulfur mine. The man-made lake had been neutralized, but bentonite rich sediments remained contaminated with very weathered hydrocarbons (sediments with $\sim 50,000-60,000 \mathrm{mg} / \mathrm{kg}$ Total Petroleum Hydrocarbons were used in this study). Biostimulation, bioaugmentation (with native microorganisms) and chemico-biological stabilization, all resulted in similar reductions (14-16\%) in the TPH concentration over a three month period. The land farming treatments resulted in variable reductions in toxicity, ranging from nil to complete, while the chemico-biological stabilization treatment, not only eliminated acute toxicity but also resulted in a slight stimulation ( 103-109\%) of the test organism in the bioassay (Microtox). All three treatments reduced polyaromatic hydrocarbons of probable carcinogenicity to below or nearly below the Mexican norms, reduced Toxic Characteristic Leaching Proceedure leachates to $<1 \mathrm{mg} / \mathrm{L}$, and left the material in a pH range of 7.0-7.8. The chemico-biological stabilization has the advantage of only requiring initial mixing of the chemical and organic reagents instead of daily aeration, thereby reducing operating costs. This method is also able to treat very difficult sites at low cost, relying on biological humification processes which are accelerated in a humid tropical and semitropical environment. The total unit cost of the chemico-biological stabilization treatment was estimated to be $\sim 60 \%$ of that for land farming in the southern Gulf of Mexico region.
\end{abstract}

Key words: Bioremediation, oil, total petroleum hydrocarbons, soil, toxicity

\section{INTRODUCTION}

Most of the methods currently used to remediate contaminated soils in emerging countries are mere adaptations of technologies originally developed in industrialized regions. However, the imported methods were designed for areas with different kinds of economies, cultural expectations and frequently, different physical and biological environments. The misuse of the imported technologies is often inadequate to the local needs when employed in developing regions. Furthermore, their implementation frequently requires the importation of materials, machinery and know-how. This creates dependence on foreign technology and increases the cost of remediation. Unfortunately, the imported technologies are usually poorly suited to the new socio-economic and physico-biological environments, and fail to succeed (McMillen et al., 2002). Besides, in many developing regions, especially in humid tropical and

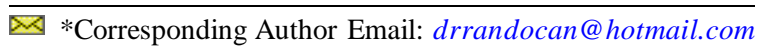
Tel: +52 993330 1244; Fax: +52 9933544308 subtropical environments, physical, chemical or biological processes occur which can be applied to the remediation of contaminated soils (Adams and Castillo, 2000).

An exception to this tendency is the ChemicoBiological Stabilization process for treating hydrocarbon contaminated soils, sediments and drilling cuttings. This process was developed in the southern Gulf of Mexico region and takes advantage of the increased rate of natural biological processes in a humid tropical environment. This method has been proven to be able to treat hydrocarbon contaminated soil and drilling cuttings with reduced labor, machinery and fuel costs rather than other commonly used methods. In the present article, this technology is compared with biostimulation (land farm) and bioaugmentation considering effectiveness, logistics and costs.

This method was developed by and for people and sites in the southern Gulf of Mexico region and can be 
implemented using locally available materials, machinery and know-how. The first steps in developing this method came from petroleum industry personnel trying to treat old drilling waste and purge pits using simple procedures that had been observed to reduce the oily appearance of contaminated materials, namely the addition on hydrated lime $\left(\mathrm{Ca}(\mathrm{OH})_{2}\right)$ or quicklime $(\mathrm{CaO})$ plus an organic absorbent (sawdust). These as well as organic rich river levee soil were mixed with the drilling and/or purge wastes and then extended as a thin layer (approx. 20-40 cm) over the surface of the site, and later planted with local grasses or allowed to become naturally colonized with local weedy vegetation. Originally, petroleum industry personnel considered adding the river levee soil to be an important source of microorganisms for biodegradation of the hydrocarbons. Using this method, some sites were partially treated, but the national environmental agency responsible to inspect remediated sites (the Federal Attorney for Environmental Protection, PROFEPA for its abbreviation in Spanish) considered that, due to the large additions of other materials, the process was simply a dilution (at that time, the addition of amendments and soil used by petroleum personnel were quite large). These sites faced serious difficulties in being considered as remediated by the authorities (PEMEX, 1995; Arroyo, 1997).

Subsequently, this method was developed technologically in a local state-run university allround the region. The method was tested systematically, altering: 1) the amount of chemical reagent, 2) the amount of organic amendment, 3) the type of organic amendment, 4) the order of application of chemical and organic amendments and 5) the elimination of exogenous soil (Adams, 2004a). It was found that the order of application was very important and the addition of organic rich soil was unnecessary (Adams, 2004b). Also, other organic amendments worked much better than the sawdust originally employed and important advances were achieved over a mediumterm period with respect to soil fertility (field capacity and water repellency, Adams et al., 2007). Furthermore, toxicity and soil leachates were demonstrated to be considerably reduced in the short term and not to present an unacceptable risk to soil or groundwater (UJAT, 2006).

Material was collected from a sediment "beach" area in a large (320 Ha) dam used to temporarily store waste runoff from a sulfur mine in the southern Veracruz State (Mexico). Sulfur was mined at this site from salt domes using the Frasch process, and acid leachate from the tailings pile was diverted to the holding dam (UNAM, 2002). During the drilling process, bentonite-based drilling fluids were used and at least part of the spent muds were also diverted to the dam, forming a large (approx. $23 \mathrm{ha}$ ) sediment "delta" or beach area in which the fine clay settled out (UJAT, 2006). Interlaced with the fine sediments are thin veins of very viscous hydrocarbons which originated from the salt domes and were considered waste material by the mine operators and discharged with the acid water and drilling fluids. This oil is slightly denser than water and has settled on the bottom of the dam just above the sediments. Outside the sediment delta area, there has been very little infiltration of this oil into the native sediments due to its viscosity. Only $13 \%$ of the dam area (not including the sediment delta) has hydrocarbons in the native sediments although approx. $60 \%$ of this same surface is covered with a layer of oil (UJAT, 2006). The very high viscosity of the oil has prevented further penetration. In gas chromatography characterization (EPA, 1997), the oil was found to be generally midrange (10 - 25 C) but extremely weathered without any peaks arising above the undefined complex mixture in chromatograms. The analytical laboratory, at which samples were processed, sent the following footnote on the analytical report: "appears to be weathered lubricant oil”. The concentration of hydrocarbons in the sediments used in this study was approx. 5-6\% (dry weight). The water in the dam had been neutralized with magnesium oxide as part of the site remediation prior to lowering the level in the dam and collecting the sediments used in this study.

\section{MATERIALS AND METHODS}

\section{Sediment collection}

Material was obtained from the sediment delta at the dam "Presa Agua de Minas", in the Texistepec Mining Unit in Texistepec Municipality, in southern Veracruz State, Mexico, in March 2004. In the area where material was collected, an oily crust of approx. $10 \mathrm{~cm}$ had already been removed manually as part of the remediation of the site. Material was collected with a straight shovel from the surface to a depth of 90-100 cm, obtaining roughly one-half cubic meter of the material. This material was placed in hard plastic 
containers and transported to the remediation patio of the Bioremediation Laboratory in the Juarez Autonomous University of Tabasco (Universidad Juárez Autónoma de Tabasco, UJAT), where it was thoroughly mixed.

\section{Experimental design}

The material was treated by three methods: 1) bioremediation - land farm with biostimulation only, 2) bioremediation - land farm with bioaugmentation, 3) chemico-biological stabilization, and a control (without treatment). Each treatment and control included three replicates. For each replicate, the material (after being mixed) was placed in cells $40 \mathrm{~cm} \mathrm{x} 40 \mathrm{~cm} \mathrm{x}$ $20 \mathrm{~cm}$ depth. The cells were formed of cinderblock and situated on a concrete slab. All tests were run in the open air in a tropical environment: $\sim 1800 \mathrm{~mm}$ annual average precipitation, $\sim 29{ }^{\circ} \mathrm{C}$ average annual temperature (West et al., 1987). The three treatments are described below:

Biostimulation: addition of inorganic nutrients (Grow-Feed 20-30-10 commercial fertilizer) sufficient to provide $100 \mathrm{ppm}$ of nitrogen, an organic amendment ( $0.74 \%$ of chopped water lily, dry weight basis), daily aeration and periodic moisture addition (to maintain approx. $15-22 \%$ moisture). The actual moisture maintained in the treatment cells was $19.3 \% \pm 1.51 \%$. Temperature was measured daily and overly high temperature was controlled by spraying a small quantity of water on the treatment cells. The average temperature in the cells during the study was $32^{\circ} \mathrm{C} \pm 2.7^{\circ} \mathrm{C}$.

Bioaugmentation: fertilizer and organic amendment addition as in the biostimulation treatment, followed by the addition of autochthonous microorganisms, aeration, and moisture control (to maintain approx. 15$22 \%$ moisture). Moisture and temperature were controlled as described for biostimulation, with the actual moisture maintained at $19.4 \% \pm 2.21 \%$, and the average temperature was the same as that in the biostimulation treatment $\left(32^{\circ} \mathrm{C} \pm 2.7^{\circ} \mathrm{C}\right)$.

Chemico-biological stabilization: addition of $4 \%$ (w/ w) hydrated lime, mixing, followed by adding 4\% (w/w) organic amendment (cachasse: sugar cane process waste) three days latter (Adams, 2004b). Fifteen days later, humidicola grass (Brachiaria humidicola) seeds were planted on the surface of the treatment cells.
Preparation of autochthonous microorganisms for bioaugmentation

Contaminated soil from the sediment delta was used as a source of microorganisms to prepare an undefined mixed culture. A 1/10 dilution of field moist sediment in deionized water was prepared, mixed thoroughly, and allowed to settle for $20 \mathrm{~min}$. One milliliter of the supernatant was collected, taking care to avoid floating particles, and used to inoculate $100 \mathrm{~mL}$ of mineral nutrient which consisted of $1 \mathrm{~g} / \mathrm{L}$ of soluble commercial fertilizer (Grow-Feed 20-30-10) in deionized water. As the $\mathrm{C}$ source, a drop of oil recovered from the contaminated sediments was added to the culture flask on the first day of incubation, followed by a drop of spent lubricant (motor oil) on the second day (the oil from the contaminated sediment was extremely viscous and produced a relatively low level of growth by itself). The culture flasks was placed on a New Brunswick Scientific model 01071-0000 orbital shaker ( 180 RPM) to aerate the culture, at room temperature $\left(\sim 28^{\circ} \mathrm{C}\right)$.

After three days, a notable increase in turbidity was observed, and the culture was used to inoculate a second culture flask using $1 \mathrm{~mL}$ of the first culture to inoculate $100 \mathrm{~mL}$ in the second culture. This process was repeated (three sequential cultures in all) to ensure that the selected microorganisms were actually using the added hydrocarbons as the $\mathrm{C}$ source and not alternative $C$ sources from the original dilution of the sediment. In the third sequential culture, growth was measured with a Spectronic 20 (Bausch and Lomb) spectophotometer at $600 \mathrm{~nm}$ using uninoculated growth medium as a blank. This third culture was started using oil from the site as a C source and after roughly three days a drop of spent lubricant was added. After another three days, another drop of spent lubricant was added. After 12 days, this culture showed an increase in absorbance of $>0.2$ O.D. and was used to inoculate the final culture used for bioaugmentation in the treatment cells.

One and one-quarter milliliter of the third sequential culture was added to each of twelve $250 \mathrm{~mL}$ flasks, each containing $125 \mathrm{~mL}$ of mineral growth medium ( $1 \mathrm{~g} / \mathrm{L}$ of Grow Feed fertilizer). One drop of oil from the site was added to each flask to start the culture. After three days and again after another three days, one drop of spent lubricant was added to each flask. After 12 days, the cultures were harvested, pooled and divided into three $500 \mathrm{~mL}$ portions. 
Each portion was added to a bioaugmentation treatment cell, applying the culture with a manual spray bottle, mixing the solution into the soil with a garden shovel. The final inoculation was estimated to be $\sim 6 \times 10^{6}$ bacteria/g of dry soil considering the turbidity of the final culture and the application rate.

\section{Monitoring}

Initially and on a monthly basis, core samples were taken from each treatment cell, from the surface to 20 cm depth and analyzed for a variety of parameters. $\mathrm{pH}$ was measured with a Corning brand, model $240 \mathrm{pH}$ meter with a Sensorex brand, model 5200c pH electrode (SECOFI, 1980).

Total Petroleum Hydrocarbons (TPH) were measured by EPA method 418.1 (EPA, 1997), using perchloroethylene as an extraction solvent with an Infracal TOG/TPH analyzer (Wilks Enterprise). Acute toxicity was measured with the Microtox system using a Microbics model 500 analyzer (SECOFI, 1996). Toxicity Characteristic Leaching Proceedure (TCLP) leachates were prepared (SEDESOL, 1993) and TPH in the TCLP leachates was measured by extraction in perchloroethylene, solvent evaporation, re-dissolution in methanol, and measurement of hydrocarbons in the methanol solution using EPA method 9074 (EPA, 1997; Adams and Ramírez, 1999). For this TPH analysis in leachate a Petroflag soil analyzer (Dexsil Corporation) was used. Samples for carcinogenic Polyaromatic Hydrocarbon (PAH) analyses were sent to a commercial laboratory accredited by the Mexican Accreditation Entity (EMA for its abbreviation in Spanish) and were analyzed by EPA method 8270 D (EPA, 1997) by gas chromatography/mass spectrometry (GC/MS) using a Hewlit Packard HP5890 GS coupled to a Hewlit Packard HP5971 MS detector, or equivalent.

\section{RESULTS AND DISCUSSION}

\section{Changes in hydrocarbon concentration}

In Fig. 1, the results of monitoring for hydrocarbon concentration are presented. All data presented are for core samples from 0-20 cm depth. During the first month of treatment, all of the processes registered a reduction in TPH concentration: 20\% for biostimulation and bioaugmentation and $12 \%$ for the chemico-biological stabilization. However, during the second month of treatment, an increase of 4-9\% in TPH concentration was observed. It is possible that this observation is due to changes in the interaction between the hydrocarbons and soil particles that make the hydrocarbons more available and results in an increase in the extraction efficiency. If the soil microorganisms begin to degrade some of the organic material in the soil (humic substrates, water lily or cachasse), this could liberate part of the hydrocarbons from soil particles. An alternative explanation could be that biosurfactants are produced by oil-degrading microorganisms, also leading to greater availability and increased extraction efficiency. It is also possible that some of the intermediates of biodegradation (alcohols, for example) produced greater IR absorbance, or were more easily extracted from the soil matrix than the original hydrocarbons. Increases of this type have also been reported by other authors during the intermediate phase of biodegradation (Adams et al., 2008; Bartha and El-Din, 1993).

During the third month of treatment, this trend (increased TPH concentration) continued in the bioaugmentation treatment (increase of an additional $5 \%$ ), but in both the biostimulation and chemicobiological stabilization treatments, important reductions were observed to be about 3.5\% for biostimulation and $9 \%$ for the chemico-biological stabilization treatment. Overall reduction during the three month period was $14-16 \%$ in each of the three treatments. Interestingly, the gas chromatography of oil from this site showed $14 \%$ of the oil to be in the C10-C15 range (with $86 \%$ $\mathrm{C}>15$ ). This overall low rate of biodegradation of very weathered hydrocarbons in soil is not unusual (Adams, et al., 2006; Atlas, 1986; Jerger et al., 1991). It probably results not only from more complexity in their chemical structure, but due to their high viscosity and reduced bioavailabilty. Similar kinds of hydrocarbons in liquid broth or slurry conditions (where surface area and bioavailability problems are mechanically overcome) have been highly biodegraded in relatively short time periods (Pradhan et al., 1997; Jerger et al., 1991).

\section{Reduction in toxicity}

The results of the toxicity evaluation are shown in Fig. 2. In this scale, toxicity is represented in toxicity units=1/EC50, where EC50 is the effective concentration-50, the concentration of the sample which reduces the activity (bioluminescence) of the test organism in the bioassay by 50\% (Bulinc, 1990). In this case, the EC50 is calculated as a proportion (75 $\%=0.75$, for example). The scale used in this study is the quarter log scale proposed by Kross and Cherryholmes (1993) normalized to the background toxicity at the site (Cornelio, 2001; UJAT, 2006). Samples in which no toxicity pattern was observed were assigned a value equivalent to the background. 
Int. J. Environ. Sci. Tech., 5 (2), 169-178, Spring 2008
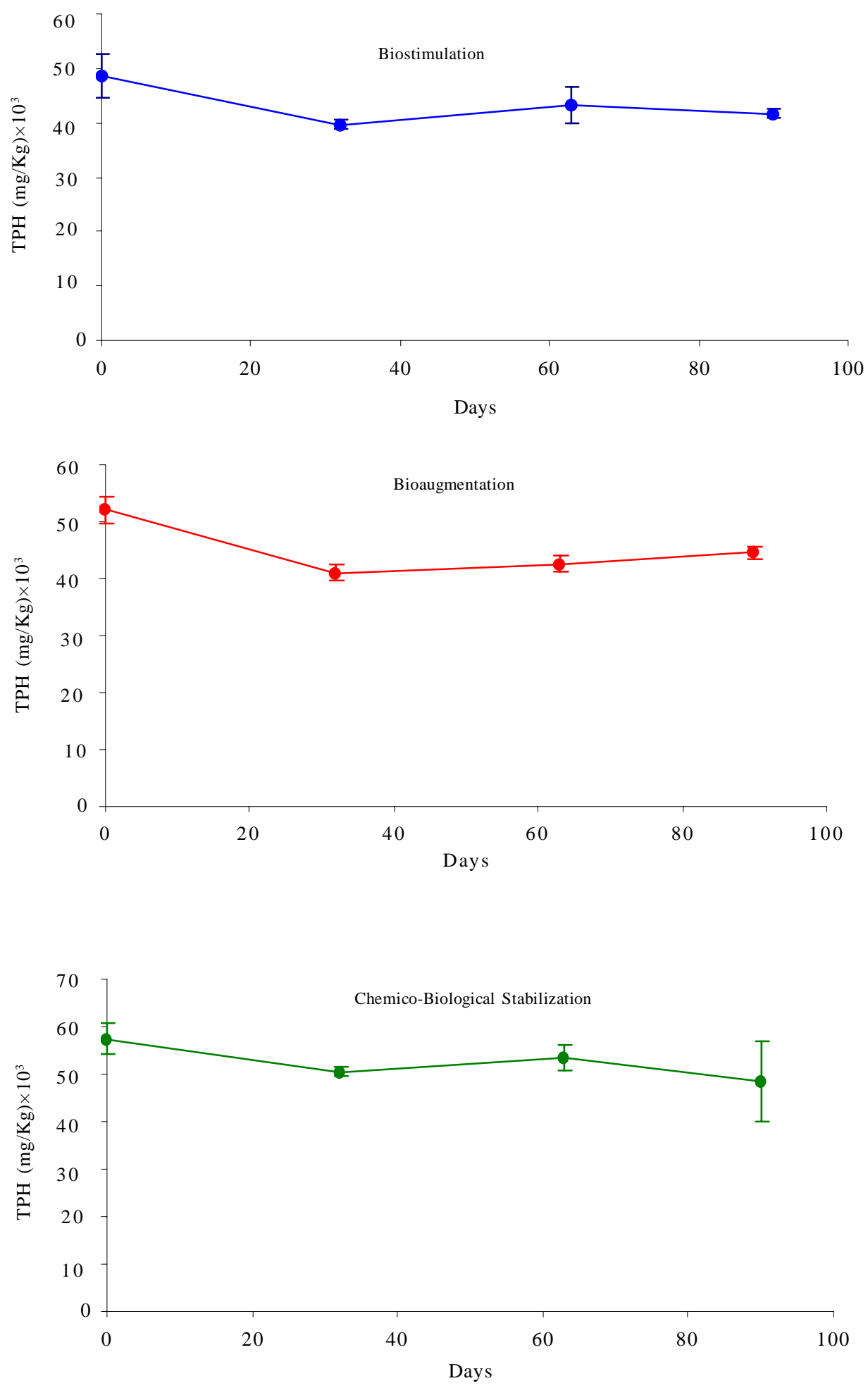

Fig 1: Changes in hydrocarbon concentration during treatments 
As Fig. 2 is shown, both the biostimulation treatment and the chemico-biological stabilization treatment reduced the toxicity to the background levels, whereas the bioaugmentation treatment in this study resulted in little if there is any change in the toxicity. Likewise, the control showed practically no change, when the variability of the data is taken into account. Both the bioaugmentation treatment and the control had the final toxicity values in the slightly toxic range.

In the chemico-biological stabilization treatment, the final material not only was intoxic but produced stimulation of the test organism in the bioassay, of 103-109\% with respect to the blank.

\section{$p H$ variation in remediation treatments}

The initial $\mathrm{pH}$ of the sediment material was slightly alkaline in the 7.5-8.0 range. During the biostimulation and bioaugmentation treatments in the first month, a slight increase was observed, raising the pH to 8.18.2, possibly due to the addition of inorganic nutrients. Following this brief raise, the $\mathrm{pH}$ dropped into the 7.0 7.8 range during the rest of the study.

In the chemico-biological stabilization treatment, a large increase in the $\mathrm{pH}$ was observed immediately after adding calcium hydroxide and reaching 11.8-11.9. However, over the next few weeks, and after the addition of cachasse, the $\mathrm{pH}$ was moderated and fell to $\sim 8.2$. Over the next couple of months, the $\mathrm{pH}$ continued to decline slightly to $\sim 7.8$.

\section{TCLP leachates}

Untreated sediment collected in this area has the potential to produce TCLP leachates of $\sim 10$ to $12 \mathrm{mg} / \mathrm{L} \mathrm{TPH}$. Following treatment by all three methods, biostimulation, bioaugmentation and chemico-biological stabilization, the TCLP leachates were reduced to below the detection limits ( $<1 \mathrm{mg} / \mathrm{L}$ in this study).

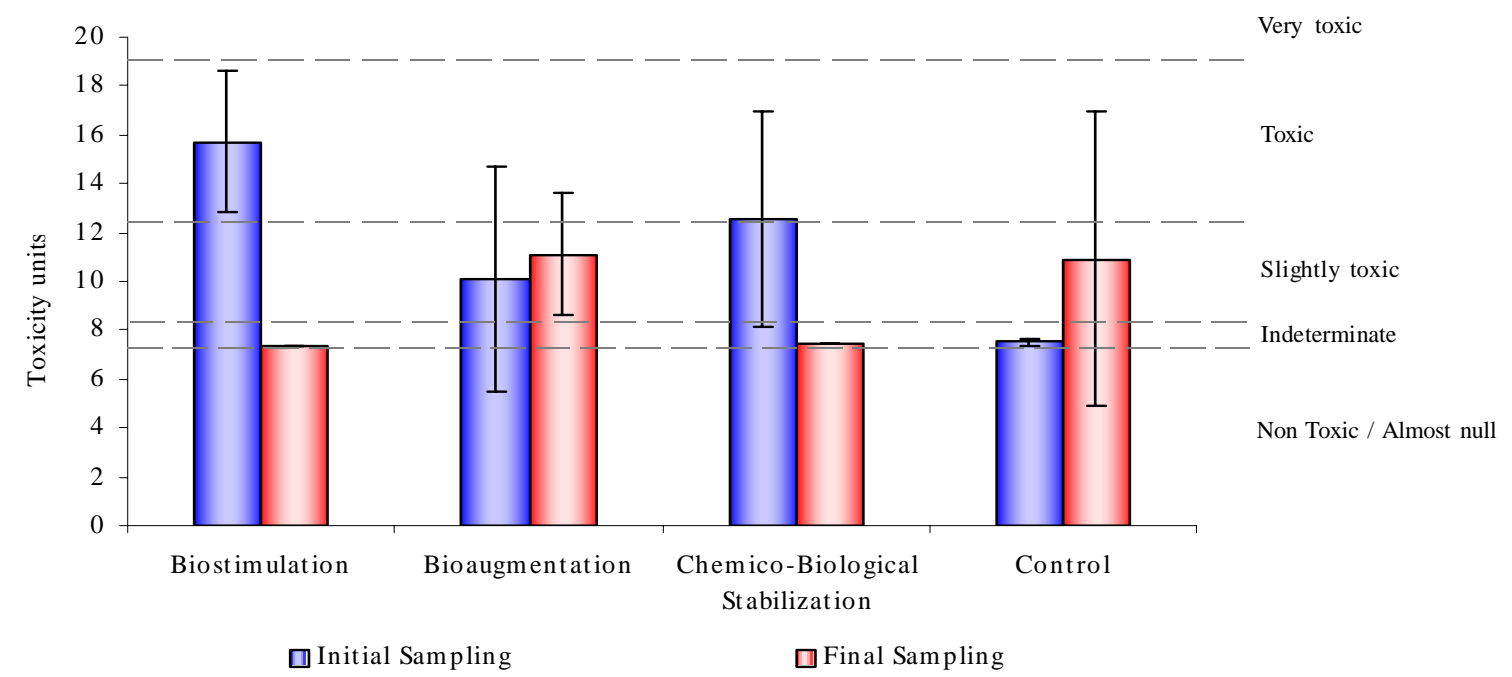

Fig. 2: Changes in toxicity in remediation treatments (Bar height represents the average of three replicates; error bar -one standard deviation

Table 1: Carcinogenic PAH concentrations in treated and untreated sediment

\begin{tabular}{|c|c|c|c|c|c|c|c|}
\hline \multirow{3}{*}{$\mathrm{PAH}$} & \multicolumn{7}{|c|}{ Concentration (mg/kg, dwt) } \\
\hline & \multicolumn{2}{|c|}{ Biostimulation } & \multicolumn{2}{|c|}{ Bioaugmentation } & \multicolumn{2}{|c|}{$\begin{array}{l}\text { Chemico-Biological } \\
\text { Stabilization }\end{array}$} & \multirow{2}{*}{${ }^{* *} \mathrm{DL}$} \\
\hline & Initial & 90 days & Initial & 90 days & Initial & 97 days & \\
\hline Benzo(a)anthracene & 1.816 & 1.306 & 1.816 & 0.217 & ND & 0.178 & 0.003 \\
\hline Benzo(b)fluoranthene & $\mathrm{ND}^{*}$ & 2.360 & ND & ND & ND & 0.360 & 0.010 \\
\hline Benzo(k)fluoranthene & ND & 3.404 & ND & ND & ND & 0.404 & 0.002 \\
\hline Benzo(a)pyrene & ND & ND & ND & ND & ND & ND & 0.009 \\
\hline Dibenzo(a,h)anthracene & ND & ND & ND & ND & ND & ND & 0.100 \\
\hline Indeno(1,2,3-cd)pyrene & ND & ND & ND & ND & ND & ND & 0.020 \\
\hline Total & 1.816 & 7.070 & 1.816 & 0.217 & ND & 0.942 & --- \\
\hline
\end{tabular}

*ND: Not detected. **DL: Detection limit 
Polycyclic Aromatic Hydrocarbons (PAHs)

Due to the lack of in-house analytical capacity and the relatively high costs of these analyses, composite samples were collected for analysis from two batches of sediment used in this study (untreated material for the biostimulation/bioaugmentation test, and untreated material for the chemico-biological stabilization test). Likewise, composite samples were collected for each of the treatments at the end of the study. These were analyzed for the six carcinogenic PAHs that are considered in the pertinent Mexican environmental regulation NOM-138-SEMARNAT/SS-2003 (SEMARNAT, 2005), namely benzo(a)anthracene, benzo(b)fluoranthene, benzo(k)fluoranthene, benzo(a)pyrene, dibenzo(a,h)anthracene and indeno(1,2,3-cd)pyrene. (Table 1 ). In both the biostimulation and chemico-biological stabilization treatments, an increase was observed in the concentration of carcinogenic PAHs. The overall increase was roughly 4 times for the biostimulation treatment and 6 times for the stabilization treatment (based on detection limits). This increase may be due to variability in sampling, but most likely is due to either changes in the matrix structure which increase extraction efficiencies or production of these compounds as intermediates in the decomposition of more complicated structures. In the bioaugmentation treatment, a decrease in carcinogenic PAH concentration was observed of more than 8 times.

In both the bioaugmentation treatment and the chemico-biological stabilization treatment, the final concentration of each of the carcinogenic PAHs was below the Mexican norms (NOM-138-SEMARNAT/SS2003; $2 \mathrm{mg} / \mathrm{kg}$ for all PAHs except for benzo(k)fluoranthene $-8 \mathrm{mg} / \mathrm{kg}$, for non-industrial sites). In the biostimulation treatment, only benzo(b)fluoranthene was slightly above the Mexican norms, $2.360 \mathrm{mg} / \mathrm{kg}$ in the treated sample vs. $2.0 \mathrm{mg} / \mathrm{kg}$ permitted. It is likely that with slightly longer treatment times all PAHs would be within the Mexican norms.

\section{Costs analysis}

Considering the regional prices of machinery rental, fuel, labor and materials costs, the treatment alternatives were evaluated for cost at the site being considered for remediation. These calculations were based on an in-place volume of $3200 \mathrm{~m}^{2}$ and an in-situ superficial application of the remediation methods.

In the regional market, the machinery rental prices are inflated with respect to national levels, due to the high demand in the petroleum industry for construction and remediation projects. These costs may be similar

Table 2: Unit cost analysis for biostimulation, bioaugmentation and chemico-biological stabilization of hydrocarbon contaminated sediments

\begin{tabular}{|c|c|c|c|c|}
\hline & \multicolumn{4}{|c|}{ Unit cost $\left(\right.$ per $\left.\mathrm{m}^{3}\right)$} \\
\hline Concept & $\%$ & Mexican pesos & $€^{*}$ & US \$* \\
\hline & \multicolumn{4}{|c|}{ Biostimulation } \\
\hline Materials & 68 & 155.94 & 9.98 & 14.24 \\
\hline Machinery & 17 & 39.89 & 2.55 & 3.64 \\
\hline Labor & 15 & 35.16 & 2.25 & 3.21 \\
\hline \multirow[t]{2}{*}{ Total } & $100 \%$ & \$ 230.99 M.N. & $€ 14.78$ & \$21.09 USD \\
\hline & \multicolumn{4}{|c|}{ Bioaugmentation } \\
\hline Concept & $\%$ & Mexican pesos & $€^{*}$ & US \$* \\
\hline Materials & 67 & 170.12 & 10.88 & 15.54 \\
\hline Machinery & 18 & 46.92 & 3.00 & 4.29 \\
\hline Labor & 15 & 37.16 & 2.38 & 3.39 \\
\hline \multirow[t]{2}{*}{ Total } & $100 \%$ & \$ 254.20 M.N. & $€ 16.26$ & \$23.22 USD \\
\hline & \multicolumn{4}{|c|}{ Chemical-Biological Stabilization } \\
\hline Concept & $\%$ & Mexican pesos & $€^{*}$ & US \$* \\
\hline Materials & 78 & 102.25 & 6.54 & 9.34 \\
\hline Machinery & 8 & 9.84 & 0.63 & 0.90 \\
\hline Labor & 14 & 17.83 & 1.14 & 1.63 \\
\hline Total & $100 \%$ & \$129.92 M.N. & $€ 8.31$ & \$11.87 USD \\
\hline
\end{tabular}


to other petroleum producing regions in developing economies, but fuel, materials and labor will probably be somewhat less than in very industrialized countries (Table 2). These costs do not include profit or taxes.

The notable difference between the biostimulation/ bioaugmentation and chemico-biological stabilization is the cost for machinery and labor, being roughly $60 \%$ less. This is due primarily to the need for frequent tilling in the biostimulation/ bioaugmentation treatments that are avoided in the chemico-biological stabilization treatment. Likewise, there are savings reflected in the materials costs, which in this case include fuel for machinery. Fuel costs for the chemico-biological stabilization treatment were estimated to be only 2-3\% of the fuel cost for biostimulation. Almost one-half of the overall cost for the chemico-biological stabilization is for the chemical reagent (hydrated lime). However, considering the savings in fuel, machinery rental and labor costs, this alternative was still estimated to be $>$ $40 \%$ more economical than biostimulation.

\section{General evaluation}

All of the three treatment methods evaluated produced similar results with respect to the reduction in hydrocarbon concentration, being 14-16\% over a three-month period. If the objective of the remediation is merely to reduce the concentration of hydrocarbons, these methods do not result in reductions sufficient to be accepted by environmental regulations in Mexico (NOM-138-SEMARNAT/SS-2003; SEMARNAT, 2003).

The TPH concentrations (after three months of treatment) were still 4-5\% ( 40,000-50,000 mg/kg). However, in Mexico, as in many other countries, riskbased remediation, including stabilization, is considered to be an acceptable alternative (SEMARNAT, 2003; SEMARNAT, 2005). In these treatments, the overall results were evaluated in terms of soil functionality, based on toxicity, leachate potential, $\mathrm{pH}$ and carcinogenic PAHs.

All of the three evaluated treatments reduced the leachate potential to non-detectable levels. The biostimulation treatment and the chemico-biological stabilization treatment completely reduced acute toxicity. Furthermore, the stabilization treatment not only reduced the acute toxicity completely but also actually caused stimulation (increased bioluminescence) in the bioassay. This bioassay is a good tool to evaluate general toxicity in the environment and the results are consistent with toxicity to soil and sediment invertebrates (Doherty, 2001).

With respect to other parameters, all of the three treatments resulted in a final $\mathrm{pH}$ of 7.0-7.8 in material with an initial $\mathrm{pH}$ of 7.5-8.0. In terms of carcinogenic PAHs, the bioaugmentation and stabilization treatments had final values that are below the permissible maximum limits in Mexico, and the biostimulation treatment only presented one $\mathrm{PAH}$ slightly above the permissible limit $(2.36 \mathrm{mg} / \mathrm{kg}$ benzo(b) fluoranthene vs. $2.0 \mathrm{mg} / \mathrm{kg}$ permitted). It is very likely that with a little longer treatment time, the biostimulation treatment would also have reduced the PAH concentration to acceptable levels.

Considering these results, both the biostimulation and chemico-biological stabilization treatment methods are acceptable alternatives at least for the remediation of this site. The bioaugmentation, however, did not reduce the acute toxicity sufficiently during the period of this study. One advantage of the chemico-biological stabilization treatment, is the biological stimulation observed in the bioassays, which may reflect better growing conditions for microorganisms in the treated material and result in better recovery of the soil ecosystem and vegetative growth (Alexander, 1995; Overton, 1996).

However, the primary advantages of the chemicobiological stabilization are logistics and cost. Since frequent tilling is not required, fuel, labor and machinery rental costs are greatly reduced. The overall cost of the chemico-biological stabilization treatment in this evaluation was less than $60 \%$ of that for biostimulation.

Based on the results of this study, chemicobiological stabilization was proposed in the remedial action plan for this site and has been approved by Mexican authorities (Ministry of the Environment and Natural Resources, SEMARNAT for its abbreviation in Spanish). This may be an important alternative for the treatment of soils, muds and sediments highly contaminated with heavily weathered hydrocarbons in tropical and subtropical environments such as southeastern Mexico, eastern Venezuela, the Niger Delta, Sumatra, Louisiana, etc.

\section{ACKNOWLEDGEMENTS}

The researchers would like to thank José Abisenas Álvarez Rivera and Elias Francisco Sigala Cardona for their valuable assistance with pilot scale studies and 
Juan Avila Gonzalez of Pemex Gas y Petroquímica Básica, for his support in the logistics related to the physical extraction of the material used in this study and for other support toward this research.

\section{REFERENCES}

Adams, R. H., (2004a). Chemical-biological stabilization method for treatment of drilling cuttings and hydrocarbon contaminated soil. $11^{\text {th. }}$ International Environmental Petroleum Conference. International Environmental Petroleum Consortium, (http://ipec.utulsa.edu), Albuquerque, N. M. $11-15$ October

Adams, R. H., (2004b). Chemical-biological stabilization of hydrocarbon contaminated soil and drilling cuttings in tropical Mexico, Land Contam. Reclam., 12 (11), 349361.

Adams, S. R. H.; Castillo, A. O., (2000). Fitorremediación y fitomitigación para restauración de localizaciones petroleras. Revista de Divulgación de la División Académica de Ciencias Biológicas de la Universidad Juárez Autónoma de Tabasco, Villahermosa. Kuxulkab, 5 (11), 30-34.

Adams, R. H.; Díaz-Ramírez, I. J.; Guzmán-Osorio, F. J.; Gutiérrez-Rojas, M., (2006). Biodegradation and detoxification of soil contaminated with heavily weathered hydrocarbons. $13^{\text {th }}$ International Environmental Petroleum Conference, International Environmental Petroleum Consortium, (http://ipec.utulsa.edu), San Atonio, Texas, 16-20 Oct.

Adams, R. H.; Guzman-Osorio, F. J.; Alvarez-Rivera, J. A.; Domínguez-Rodriguez, V. I., (2007). Long term fertility monitoring of soil treated by the chemical-biological stabilization method. $14^{\text {th. }}$ International Environmental Petroleum Conference, International Environmental Petroleum Consortium, (http://ipec.utulsa.edu), Houston, Texas, 6-9 Nov.

Adams, S. R. H.; Ramírez, A. J., (1999). Optimización del método EPA 9074 como alternativa para análisis de hidrocarburos totales de petróleo. VI Congreso InterAmericano Sobre el Medio Ambiente. Red Interamericana para la Calidad Ambiental/Instituto Tecnológico de Educación Superior de Monterrey (ITESM), Monterrey, Nuevo León, México. Sept./Oct.

Adams, S. R. H., Kanga L. K.; Guzmán, O. F. J., (2008). Manejo de humedad para la biorremediación de suelo contaminado con hidrocarburos del petróleo. Universidad y Ciencia, en revisión.

Alexander, M., (1995), How toxic are toxic chemicals in soil. Environ. Sci. Tech., 29 (11), 2713 - 2717.

Arroyo, A. L., (1997), Saneamiento ecológico en presas de terracerías impactadas por hidrocarburos y desechos de perforación (alternativa), Distrito Cárdenas, Tabasco, México, PEMEX Exploración y Producción - SIPA, Gaceta Ecológica, 12-14.

Atlas, R. M., (1986). Biodegradation of hydrocarbons in the environment: In: Environmental biotechnology, reducing risks from environmental chemical through biotechnology (G.S. Omen, Ed.) Plenum Press, New York.

Bartha, R.; El-Din, N. S., (1993). Testing of some assumptions about biodegradability in soil as measured by carbon dioxide evolution. Appl. Environ. Microbiol., 59 (4), 1202-1205.
Bulinc, A. A., (1990). The luminescent bacteria toxicity test: its potencial as an in vitro alternative. J. Biolum. Chemilum., 5 (2), 71-77.

Cornelio, G. Y.; de, J., (2001). Evaluación preliminar de toxicidad por plaguicidas (mancozeb) en agua y sedimentos en la zona platanera del Río Teapa, Tabasco, México, Tesis de Licenciatura en Ingeniería Ambiental. Villahermosa, Tabasco, México, División Académica de Ciencias Biológicas, Universidad Juárez Autónoma de Tabasco.

Doherty, F. G., (2001). A reveiw of the microtox toxicity test system for assessing toxicity of sediments and soils. Water Qual. Res. J. Can., 36 (3), 475-518.

EPA (1997). Test methods for evaluating solid waste: Physical/ chemical methods, Environmental Protection Agency, Publication No. EPA 530/SW-846.

Jerger, D. E.; Greenwald, B. P.; Meardon, J. A.; Exner, J. H.; Allen, M. W., (1991), Bioremediation of PCP-and creosotecontaminated soil and groundwater. $4^{\text {th. }}$ International IGT symposium on gas, oil, and environmental biotechnology. Colorado Springs, CO., 9-11 Dec.

Kross, B. C.; Cherryholmes, K., (1993). Toxicity screening of sanitary landfill leachates: a comparative evaluation with Microtox analyses, chemical, and other toxicity screening methods. In: Richardson ML, editor. Ecotoxicology Monitoring. Weinheim FRG and New York: VCH Publishers: 225-49.

McMillen, S.; Smart, R.; Bernier, R., (2002), Biotreating E and P wastes: Lessons learned from 1992-2002. $9^{\text {th. }}$ International Environmental Petroleum Conference. International Environmental Petroleum Consortium, (http:/ /ipec.utulsa.edu), Albuquerque, N.M. 22-25, Oct.

Overton, E. B.; Henry, C. B. Jr.; Willison, V.; Mendelssohn, I., (1996). Application of Microtox ${ }^{\mathrm{TM}}$ assay to establish and evaluate the efficacy of in-situ burning of oiled marshes. Louisiana Oil Spill Coordinator's Office/Office of the Governor, Louisiana Applied Oil Spill Research and Development Program, OSRADP Technical Report Series 96.

PEMEX Exploración y Producción - SIPA, (1995), Tratamiento de Residuos Aceitosos y Restauración de Áreas Afectadas por Hidrocarburos, Distrito de Poza Rica, Veracruz, México, Petróleos Mexicanos, Seguridad Industrialy Protección Ambiental (SIPA) (Reporte técnica). (Reporte técnica).

Pradhan, S. P.; Paterek, J. R.; Liu, B. Y.; Conrad, J. R.; Srivastava, V. J., (1997), Pilot-scale bioremediation of PAHcontaminated soils. Appl. Biochem. Biotech., 63 (5), 759773.

SECOFI (1980). Norma Mexicana NMX-AA-008 AguasDeterminación de $\mathrm{pH}$ - Método potenciometro. Secretaría de Comercio y Fomento Industrial, México, D. F., Diario Oficial de la Federación.

SECOFI (1996). Norma Mexicana NMX-AA-112-1995-SCFI, Análisis de agua y sedimento - Evaluación de toxicidad aguda con Photobacterium phosphoreum - Método de prueba, Secretaría de Comercio y Fomento Industrial, México D.F., Dirección General de Normas.

SEDESOL (1993). Norma Oficial Mexicana NOM-053-ECOL1993, Que establece el procedimiento para llevar a cabo la prueba de extracción para determinar los constituyentes que hacen a un residuo peligroso por su toxicidad al ambiente, México D.F., Diario Oficial de la Federación. 
SEMARNAT (2003). Ley general para la prevención y gestión integral de los residuos, Secretaría del Medio Ambiente y Recursos Naturales México, D. F., Diario Oficial de la Federación.

SEMARNAT (2005). Norma Oficial Mexicana NOM-138SEMARNAT/SS-2003, Secretaría del Medio Ambiente y Recursos Naturales, Límites máximos permisibles de hidrocarburos en suelos y las especificaciones para su caracterización y remediación, México, D.F., Diario Oficial de la Federación.

UJAT (2006). Universidad Juárez Autónoma de Tabasco Caracterización físico-química y toxicológica de la Presa Agua de Mina y Presa Anexa, Unidad Minera Texistepec:
Sedimentos. Convenio UJAT-Pemex Gas y Petroquímica Básica PGPB-SGLPB-UJAT.

UNAM (2002). Instituto de Ingeniería, Universidad Nacional de México, Diagnóstico de las presas existentes en la Unidad Minera Industrial Texistepec, México, D. F., UNAM/Pemex Gas y Petroquímica Básica.

West, R. C.; Psuty, N. P.; Thom, B. G., (1987), Las tierras bajas de Tabasco en el Sureste de México. Gobierno del Estado de Tabasco, Villahermosa, Tabasco.

\section{AUTHOR (S) BIOSKETCHES}

Adams, R. H., Research professor, Juarez Autonomous University of Tabasco (Universidad Juárez Autónoma de Tabasco - UJAT), in the southern Gulf of Mexico region. His research interests include establishing riskbased remediation and restoration goals, and developing novel site remediation methods, especially for rural environments in tropical and subtropical regions within developing economies. Email:drrandocan@hotmail.com

Guzmán-Osorio. F. J., Senior research technician, Juarez Autonomous University of Tabasco (UJAT). This study is part of his bachelor's thesis and is representative of the kind of research of interest to him, including chemical stabilization/solidification, cation exchange, phytoremediation and soil water repellency issues. Email: franjaguoso@hotmail.com

This article should be referenced as follows:

Adams, R. H.; Guzmán-Osorio, F. J., (2008). Evaluation of land farming and chemico-biological stabilization for treatment of heavily contaminated sediments in a tropical environment. Int. J. Environ. Sci. Tech., 5 (2), $169-178$. 